\title{
Spectrophotometric Determination of the Trace Amount of Thallium in Water and Urine Samples by Novel Oxidative Coupling Reaction
}

\author{
P. NAGARAJA*, N. GHLLAB SAEED Al-TAYAR, \\ A. SHIVAKUMAR, A. K. SHRESTA and A. K. GOWDA \\ Department of Studies in Chemistry, \\ University of Mysore, Manasagangotri, Mysore 570 006, India. \\ drpn58@yahoo.co.in
}

Received 16 November 2008; Accepted 16 January 2009

\begin{abstract}
A novel, simple, rapid, sensitive and selective method has been proposed for the trace determination of thallium by spectrophotometric detection. This method is based on the oxidation of MBTH (3-methyl-2-benzothiazolinone hydrazone hydrochloride) by thallium(III) to form diazonium cation, which couples with IPH (Imipramine hydrochloride) in phosphoric acid medium at room temperature giving a blue colored species having a maximum absorption at $635 \mathrm{~nm}$. The reagents and manifold variables influences on the sensitivity were investigated and the optimum reaction conditions have been established. The calibration curve was found to be linear over the range $0.1-5 \mu \mathrm{g} \mathrm{mL}^{-1}$ with the molar absorptivity and Sandell's sensitivity of $2.9 \times 10^{4} \mathrm{~L} \mathrm{~mol}^{-1} \mathrm{~cm}^{-1}, 0.0071 \mu \mathrm{g} \mathrm{cm}$ respectively. The tolerance limit of the method towards various ions usually associated with thallium has been detected. The relative standard deviation for five replicate determination of $2 \mu \mathrm{g} \mathrm{mL}^{-1}$ thallium was $0.47 \%$. The method has been successfully applied for the determination of thallium(III) and thallium(I) in synthetic, standard reference materials, water and urine samples with satisfactory results. The performance of the proposed method was evaluated in terms of student's t-test and variance ratio F-test, to find out the significance of proposed method over the reported methods.
\end{abstract}

Keywords: Spectrophotometry, MBTH, Imipramine hydrochloride, Thallium, Water and Urine samples.

\section{Introduction}

Thallium is introduced into the environment by the combustion of coal and as a waste product from the production of zinc, lead and cadmium. The main source of thallium pollution at present is cement production. Despite high chronic and cumulative toxic effects 
compared with that of lead, mercury and cadmium ${ }^{1}$, its compounds are commonly used in medicines for dermatological disorders, dye pigments, photo chromic glasses, fungicides, insecticides and rodenticides, it is also included as a component of corrosion-resistance alloys $^{2,3}$. Thallium is a well-known neurotoxicant ${ }^{4}$ and has become a very important pollutant of the environment and was included in the list of 129 so-called "priority pollutants" by the US Environmental Protection Agency. It is regarded as one of the most toxic of the heavy metals, causing both chronic and acute poisoning ${ }^{5}$. Both oxidation states $\mathrm{Tl}(\mathrm{I})$ and $\mathrm{Tl}(\mathrm{III})$ exhibit biologically and toxically activation ${ }^{6}$, but $\mathrm{Tl}(\mathrm{I})$ is more toxic and reactive form of thallium(III). It has been found that $\mathrm{Tl}(\mathrm{I})$ can be replaced with potassium ions in the activation of enzymes ${ }^{7}$. Thallium and its compounds are extremely toxic; skin-contact, ingestion and inhalation are all dangerous. Thallium causes gastrointestinal irritation and disorders of the nervous system after exposure for relatively short times. In the long term, this has the potential to cause effects such as changes in blood chemistry, damage to liver, kidney, intestinal, testicular tissue, and hair $\operatorname{loss}^{8}$, also it causes abdominal pain, diarrhea and tingling in the four extremities ${ }^{9}$. The highest concentration of thallium after poisoning is in the kidney and urine ${ }^{10}$ and can be identified in urine within a few hours ${ }^{11}$. The increasing environmental and biological importance of thallium and its acute toxicity have made it necessary to develop sensitive and selective methods to determine its presence in diverse samples, in trace amounts. Various analytical techniques developed so far as cathodic and anodic stripping voltammetry (ASV) ${ }^{12-16}$, inductively coupled plasma mass spectrometry (ICP-MS) ${ }^{17}$, atomic absorption spectrometry $(\mathrm{AAS})^{18-20}$, thermal neutron activation analysis ${ }^{21}$ and electrothermal atomic absorption spectrometry ${ }^{22-24}$ have been used for trace determination of thallium(III). But its determination in real sample is complicated by interferences from coexisting metal ions $(50 \% \text { in the case of } \mathrm{Cd})^{25}$ and organic residues in the sample matrixes ${ }^{26}$. This necessitates pretreatment of the sample ${ }^{27,28}$. Some of these methods have disadvantages in terms of coast and instruments used in routine analysis.

Spectrphotometric methods have been used for the determination of thallium occurring in many samples. Several reagents such as brilliant green ${ }^{29}$, alizarin violet ${ }^{30}$, pyronin $\mathrm{G}^{31}$, 9,10-phenanthaquinone monoethylthiosemicarbazone ${ }^{32}$, metheomebrazine hydrochloride ${ }^{33}$, $N, N$-diphenyle benzaamidine ${ }^{34}$, iodide and rhodamine $\mathrm{B}^{35}$ and 4-(4- $N, N$-Dimethyl amino phenyl) urazol ${ }^{36}$, have been employed for the spectrophotometric determination of thallium. Some of these methods are unsatisfactory and impractical for routine analysis because of either poor selectivity or need preconcentration and prior extraction. Some of these analytical methods use reagents or generate chemical wastes, which are more toxic than thallium. As a consequence, the analytical methods with high performance but which are not environmentally friendly are not acceptable. Hence, there is a great need to develop methods which are less harmful to human and to the environment as one of the basic principles of Green Chemistry $^{37}$. The availability of the spectrophotometric apparatus and the simplicity of the analytical procedures make the technique very attractive for a wide range of applications. This case has encouraged the investigators to develop a simple, rapid, sensitive, selective and reliable spectrophotometric method for the determination of thallium (III) in various samples. The recommended method is based on the oxidation of MBTH by thallium(III) to form diazonium cation, which gets couple with imipramine hydrochloride in phosphoric acid medium to give a blue colored species. The method has been successfully applied in the determination of thallium in synthetic, water and human urine samples. The proposed method is sensitive, selective, inexpensive, rapid, and free from various interfering ions and doesn't need extraction and close control of $\mathrm{pH}$ or heating step. 


\section{Experimental}

A JASCO Model UVIDEC-610 UV/VIS spectrophotometer with $1 \mathrm{~cm}$-matched cells was used for all the spectral measurements. A pH-meter, EQUIP-TRONICS Model EQ-614 was employed for measuring $\mathrm{pH}$ values.

\section{Reagents and solutions}

All the chemicals used were of analytical reagent grade or the highest purity available. Doubly distilled water was used throughout the experiments for dilution of the reagents and samples. Glass vessels were cleaned by soaking in acidified solution of $\mathrm{KMnO}_{4}$ or $\mathrm{K}_{2} \mathrm{Cr}_{2} \mathrm{O}_{7}$, followed by washing with concentrated $\mathrm{HNO}_{3}$ and rinsing several times with distilled water.

Standard thallium(III) solution $\left(1000 \mu \mathrm{g} \mathrm{mL}^{-1}\right)$ was prepared by dissolving $0.112 \mathrm{~g}$ of $\mathrm{Tl}_{2} \mathrm{O}_{3}$ (Fluka, Switzerland) in $50 \mathrm{~mL}$ of $2 \mathrm{~N}$ sulphuric acid and kept aside for over night, followed by diluting to $100 \mathrm{~mL}$ in a calibrated flask with distilled water. The stock solution was standardized titrimetrically ${ }^{38}$, and solutions of lower concentrations were prepared by diluting the standard solution as and whenever required.

A stock solution of standard thallium(I) solution $\left(1000 \mu \mathrm{g} \mathrm{mL} \mathrm{L}^{-1}\right)$ was prepared by dissolving $0.117 \mathrm{~g}$ of $\mathrm{TlCl}$ (Fluka, Switzerland) in $100 \mathrm{~mL}$ of distilled water, and solutions of lower concentrations were prepared by diluting the stock solution as and whenever required.

A $0.01 \%(\mathrm{w} / \mathrm{v})$ aqueous solution of 3-methyl-2-benzothiazolinonehydrazone hydrochloride (MBTH) was freshly prepared by dissolving the requisite amount of MBTH (Merck, Germany) in distilled water and stored in dark colored bottle in a refrigerator maintaining temperature of $0-10{ }^{\circ} \mathrm{C}$. This solution thus stored was stable for 10 days.

A $0.2 \%(w / v)$ solution of imipramine hydrochloride (IPH) was prepared by dissolving the requisite amount of IPH (BDH, England) in water and stored in dark colored bottle in refrigerator maintaining temperature between $0-10{ }^{\circ} \mathrm{C}$, the solution thus stored was stable for one month.

A 5 M Orthophosphoric acid was prepared by suitable dilution of concentrated orthophosphoric acid (Ranbaxy, India) in doubly distilled water. Solutions containing suitable concentrations of potentially interfering ions were prepared in doubly distilled water or appropriate solvent, whenever required.

All the other solutions used through the experiments like sulphuric acid, bromine water, sulphamic acid and sodium fluoride were prepared by dissolving requisite amounts of the reagents in doubly distilled water.

\section{Recommended procedure}

Determination of thallium(III)

An aliquot of a sample solution containing 1-50 $\mu \mathrm{g}$ of thallium(III) was transferred into a series of $10 \mathrm{~mL}$ calibrated flasks, to which $1 \mathrm{~mL}$ of $0.01 \%$ of MBTH, $1 \mathrm{~mL}$ of $0.2 \% \mathrm{IPH}$ and $1 \mathrm{~mL}$ of $3 \mathrm{M}$ orthophosphoric acid were added. Then diluted to the mark with distilled water and mixed thoroughly. The blue color, which developed within 10 minutes at room temperature, was stable for 36 hours. The absorbance was measured at $635 \mathrm{~nm}$ against the corresponding reagent blank, and the calibration graph was constructed.

\section{Determination of thallium(I)}

An aliquot of a sample solution containing 1-50 $\mu \mathrm{g}$ of thallium(I) was transferred into a series of $10 \mathrm{~mL}$ calibrated flasks, $0.1 \mathrm{~mL}(1 \%)$ bromine water was added to oxidize Thallium(I) to thallium(III) and heated to near dryness. Then $0.2 \mathrm{~mL}$ phenol was added to remove any excess of bromine water and the above procedure for the determination of thallium(III) was followed. 


\section{Determination of thallium(I) and thallium(III) in the mixture}

For the determination of thallium(I) in a composite mixture containing both oxidation states of thallium, samples containing equal quantity of spiked thallium(I) and thallium(III) was taken in two $10 \mathrm{~mL}$ standard flasks. Recommended procedure for the determination of thallium(III) carried out for one standard flask, and thallium(III) was determined from Beer's law graph. For the second standard flask, the procedure for the determination of thallium(I) was carried out. So thallium(I) was determined by the difference in obtained in the oxidized [representing both $\mathrm{Tl}(\mathrm{I})$ and $\mathrm{Tl}(\mathrm{III})$ ] and the unoxidised [representing $\mathrm{Tl}(\mathrm{III})$ samples].

\section{Determination of thallium in water samples}

Determination of thallium was carried out in environmental samples that were previously tested negative for thallium. Then river, lake and tap water samples spiked with thallium at a concentration within Beer's law limit were applied for the analysis .The spectrophotometric determination for the thallium analysis was carried out as per the procedure outlined above.

\section{Determination of thallium in urine samples}

Thallium may enter human body either deliberately as a component of drug or through contamination in water or food etc. Thus, its quantification in biological fluid is anticipated. A known amount of thallium(III) was added to $30 \mathrm{~mL}$ of healthy human urine that was previously tested negative for thallium, which was taken in a $100 \mathrm{~mL}$ micro-Kjeldahl flask, a glass bead and $5 \mathrm{~mL}$ of concentrated nitric acid were added and the flask was placed on the digester under gentle heating. When the initial brisk reaction was over, the solution was removed and cooled. Then $1 \mathrm{~mL}$ of concentrated sulphuric acid was added carefully followed by the addition of $1 \mathrm{~mL}$ of $70 \%$ perchloric acid and heating was continued to dense white fumes, repeating nitric acid addition if necessary. Further, heating was carried out for at least $30 \mathrm{~min}$, followed by cooling. The contents of the flask were filtered and diluted up to the mark with distilled water in $100 \mathrm{~mL}$ calibrated flask. A suitable aliquot of urine sample was taken and analyzed by using the procedure outlined earlier.

\section{Determination of thallium in synthetic mixtures}

Certified samples of thallium were not available, therefore, composition of spiked synthetic mixtures of common metal ions that usually accompany thallium in natural samples were prepared in concentrations below the tolerance limit ${ }^{15}$, and analyzed directly by proposed method without any prior separation of thallium.

\section{Results and Discussion}

MBTH gets oxidized by thallium(III) in an aqueous medium at room temperature to form diazonium cation, which instantaneously gets coupled with IPH in orthophosphoric acid medium, resulting in the formation of a blue colored species.

\section{Spectral characteristics}

In proposed method a blue colored product was formed and to have minimum interference, it was necessary to found out the optimum wavelength for thallium determination. This wavelength must be specific for the quantitative and specific monitoring of ThalliumMBTH-IPH. The wavelength of maximum absorbance was identified by scanning the blue colored product over the range 400-750 nm with different concentrations of thallium(III). The optimum wavelength for getting the best results was found to be $635 \mathrm{~nm}$ and the reagent blanks had negligible absorption at this wavelength. The absorption spectra of the product are shown in Figure 1. 


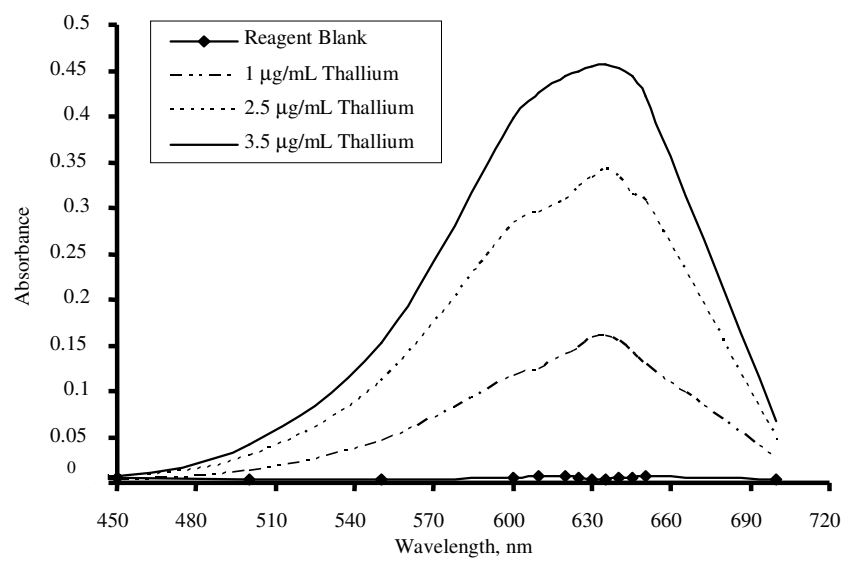

Figure 1. Absorption spectra of thallium(III) with MBTH \& IPH.

\section{Optimum reagents concentrations}

The effect of MBTH, IPH were studied by using a fixed thallium(III) concentration in $10 \mathrm{~mL}$ standard flask. It was found that $0.01 \% \mathrm{MBTH}$ in the range of $0.1-2 \mathrm{~mL}$ was necessary to get the blue color. Hence, $0.5 \mathrm{~mL}$ of $0.01 \% \mathrm{MBTH}$ was selected to get the maximum color intensity and used for further studies. Also, a $0.2 \%$ of IPH in the range of 0.1-2 mL was necessary to get the blue color. Therefore, $1 \mathrm{~mL}$ of $0.2 \% \mathrm{IPH}$ was selected to get the maximum color intensity. Excellent results were obtained using distilled water for dilution of the color product compare to the other solvents.

\section{Effect of different acids}

The effect of different acids on the stability and sensitivity of the colored species was studied with the optimum conditions. Various acids like hydrochloric acid, orthophosphoric acid, sulphuric acid and acetic acid were used at their optimum concentrations. The calibration graphs were plotted for the results obtained for the determination of different concentrations of thallium(III) within Beer's law range as shown in Figure 2, which indicated that hydrochloric acid has given color instantaneously with good sensitivity but blank color was increasing, whereas acetic acid gave less absorbance and had less sensitivity. Although sulphuric acid has given high absorbance but selectivity was less. Orthophosphoric acid showed highest sensitivity, selectivity, linearity and stability of blue colored product and the blank remained colorless. Hence, $1 \mathrm{~mL}$ of $5 \mathrm{M}$ orthophosphoric acid was chosen as the optimal acidic medium for the determination of thallium(III) in total volume of $10 \mathrm{~mL}$ to give maximum color intensity as well as stability of the colored product.

\section{Order of addition of the reactants}

The effect of order of addition of the reactants was studied by using different orders of the optimized amounts of reactants following the proposed method. The results obtained have showed that, the order of reactants addition have no effect on the absorbance values as shown in Table 1, but for maintaining the uniformity of the order of reactants addition, series No. 2 of Table 1 was followed throughout course of the determination of thallium(III).

\section{Performance of the system for a thallium determination}

In order to test the applicability of the proposed analytical technique, the absorbance of a series of solution, containing varying amounts of thallium within the Beer's law limit, were recorded against the corresponding reagent blank at $635 \mathrm{~nm}$. The beer's law limits, molar 
absorptivity, Sandell's sensitivity and optimum range by spectrophotometric determination are summarized in the Table 2. The slope, intercept and relative standard deviation were evaluated, which are included in the same table.

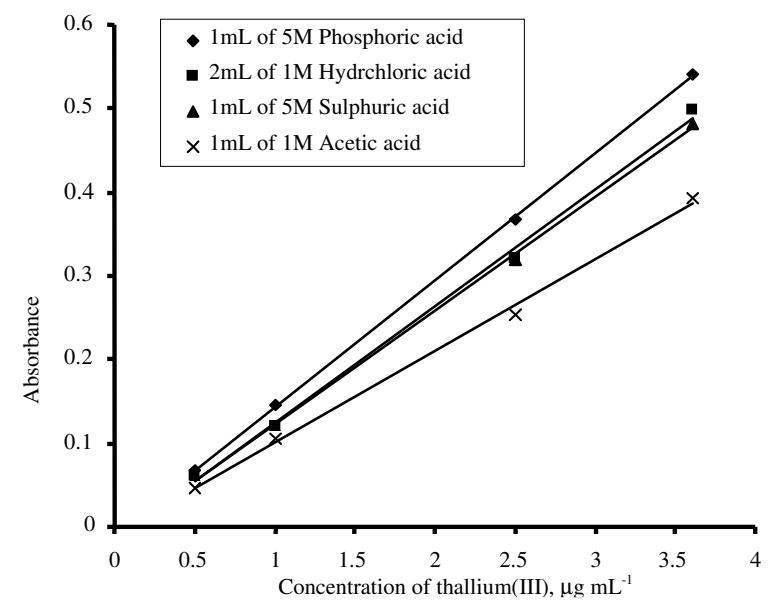

Figure 2. Effect of different acids.

Table 1. Effect of order of reactants addition.

\begin{tabular}{lcc}
\hline S No. & Order of addition $^{\mathrm{a}}$ & Absorbance for $2 \mu \mathrm{g} \mathrm{mL}^{-1}$ \\
\hline 1 & $\mathrm{~A}+\mathrm{B}+\mathrm{C}+\mathrm{D}$ & 0.398 \\
2 & $\mathrm{~A}+\mathrm{B}+\mathrm{D}+\mathrm{C}$ & 0.399 \\
3 & $\mathrm{~A}+\mathrm{D}+\mathrm{C}+\mathrm{B}$ & 0.397 \\
4 & $\mathrm{~B}+\mathrm{C}+\mathrm{A}+\mathrm{D}$ & 0.397 \\
5 & $\mathrm{~B}+\mathrm{D}+\mathrm{A}+\mathrm{C}$ & 0.397 \\
6 & $\mathrm{~B}+\mathrm{D}+\mathrm{C}+\mathrm{A}$ & 0.397 \\
\hline
\end{tabular}

Table 2. Optical parameters for the determination of Thallium(III).

\begin{tabular}{ll}
\hline Parameters & Characteristic \\
\hline Colour & Blue \\
$\lambda_{\max }, \mathrm{nm}$ & 635 \\
Stability, h & 24 \\
Beer's law range, $\mu \mathrm{g} \mathrm{mL}^{-1}$ & $0.1-5$ \\
Molar absorptivity, $\mathrm{L} \mathrm{mol}^{-1} \mathrm{~cm}^{-1}$ & $2.9 \times 10^{4}$ \\
Sandell's sensitivity, $\mu \mathrm{g} \mathrm{cm}^{-2}$ & 0.0071 \\
Optimum photometric range, $\mu \mathrm{g} \mathrm{mL}^{-1}$ & $0.2-4.5$ \\
Detection Limit, $\mu \mathrm{g} \mathrm{\textrm {mL } ^ { - 1 }}$. & 0.011 \\
Quantification Limit, $\mu \mathrm{g} \mathrm{mL}^{-1}$. & 0.033 \\
Regression Equation & \\
Correlation coefficient & \\
Slope(a) & 0.9998 \\
Intercept(b) & 0.145 \\
Standard deviation & 0.004 \\
Relative standard deviation & , $\%$ \\
Reaction time, min & 0.122 \\
$Y=a x+b$ where $x$ is the concentration of Thallium(III) in $\mu g \mathrm{~mL}^{-1} .{ }^{b}$ Ten replicates.
\end{tabular}




\section{Precision and accuracy of the proposed method}

The precision and accuracy of the proposed method were studied by analyzing solutions containing of 1,3 and $4 \mu \mathrm{g} \mathrm{mL} \mathrm{m}^{-1}$ of thallium(III) using proposed method. Ten replicate determination of each concentration gave (RSD \%) of $0.4,0.6$ and $0.5 \%$ respectively. The lower values of the relative standard deviation indicate high precision and accuracy of the method.

\section{Effect of diverse species}

In order to evaluate the suitability of the recommended method for the spectrophotometric determination of thallium(III), the effect of some foreign species commonly accompany thallium(III) were studied by adding known amounts of diverse ions to a standard thallium solution. The tolerance limit given in Table 3, was defined as the concentration of foreign species that caused an error of $\pm 3 \%$ or less in the determination of $2 \mu \mathrm{g} \mathrm{mL}^{-1}$ of thallium(III) by the recommended method. The analyses were shown that there was noninterference by most of the cations and anions, except for $\mathrm{Cr}^{6+}$, which would be tolerated at low concentration level. The use of masking agents in the analytical procedure increases the tolerance limit of some of the ions, such as using sodium fluoride to mask $\mathrm{Fe}^{2+}, \mathrm{Fe}^{3+}$. As shown in Table 3 .

Table 3. Effect of diverse ions on the spectrophotometric determination of Thallium(III) $\left(2 \mu \mathrm{g} \mathrm{mL} \mathrm{m}^{-1}\right)$.

\begin{tabular}{|c|c|c|c|}
\hline Diverse species & $\begin{array}{l}\text { Tolerance limit } \\
\qquad \mu \mathrm{g} \mathrm{mL}\end{array}$ & Diverse species & $\begin{array}{l}\text { Tolerance limit, } \\
\qquad \mu \mathrm{g} \mathrm{mL}\end{array}$ \\
\hline Urea & 100000 & Thallium(I) & 700 \\
\hline Sulphamic acid & 80000 & $\mathrm{Cd}^{2+}, \mathrm{NO}_{2}^{-\mathrm{a}}, \mathrm{Hg}^{2+}$, & 500 \\
\hline $\mathrm{NO}_{3}^{-(\mathrm{a})}, \mathrm{PO}_{4}^{3-}, \mathrm{SO}_{4}{ }^{2-}$, & 35000 & $\mathrm{Mn}^{2+}, \mathrm{Cl}^{-}$ & \\
\hline $\mathrm{Mg}^{2+}$ & & Tartarate, $\mathrm{Ni}^{2+}$ & 250 \\
\hline $\mathrm{Al}^{3+}, \mathrm{Ca}^{2+}$ & 15000 & $\mathrm{Fe}^{3+\mathrm{b}}$ & 150 \\
\hline Phenol & 5000 & $\mathrm{Ce}^{4+c}$ & 100 \\
\hline $\mathrm{Zn}^{2+}, \mathrm{SO}_{3}{ }^{2-}, \mathrm{Na}^{+}, \mathrm{K}^{+}$, & 3000 & $\mathrm{Ba}^{2+}, \mathrm{Mo}^{6+}$ & 75 \\
\hline $\mathrm{Fe}^{2+\mathrm{b}}, \mathrm{F}^{-}$ & & $\mathrm{WO}_{4}^{-}, \mathrm{Cu}^{2+}, \mathrm{Pb}^{2+}$ & 50 \\
\hline Perchlorate, $\mathrm{CH}_{3} \mathrm{COO}^{-}$ & 2000 & $\mathrm{Br}^{-\mathrm{d}^{+}}$ & 25 \\
\hline Hydroxylamine & 1500 & Dichromate & 1 \\
\hline
\end{tabular}

${ }^{a}$. Masking by the addition of $2 \mathrm{~mL}$ of $1 \mathrm{M}$ sulphamic acid,

${ }^{b}$. Masking by the addition of $4 \mathrm{~mL} 0.3 \mathrm{M}$ sodium fluoride,

c. Masking by addition $2 \mathrm{~mL} 1 \mathrm{M}$ of hydroxylamine,

${ }^{d}$. Masking by the addition of $4 \mathrm{~mL} 10 \%$ of urea.

\section{Effect of time and temperature on color stability}

Under the optimized conditions, although the color developed instantaneously, 10 min were allowed to obtain the maximum and constant absorbance the colored product was stable for 24 hour. The absorbance varied by not more than $3 \%$ over a period of 36 hour and the color development was independent of temperature in the range of $10-90{ }^{\circ} \mathrm{C}$. Hence, $10 \mathrm{~min}$ reaction at room temperature was sufficient for the routine analysis.

\section{Reaction mechanism}

Under the reaction conditions, MBTH loses $2 \mathrm{e}^{-}$and a proton on oxidation with thallium(III) forming the electrophilic intermediate (active coupling species) which couples with IPH to give a blue colored product. The probable reaction pathway based on the reactivity of MBTH with aromatic amines ${ }^{39-41}$ is shown in Scheme 1. 

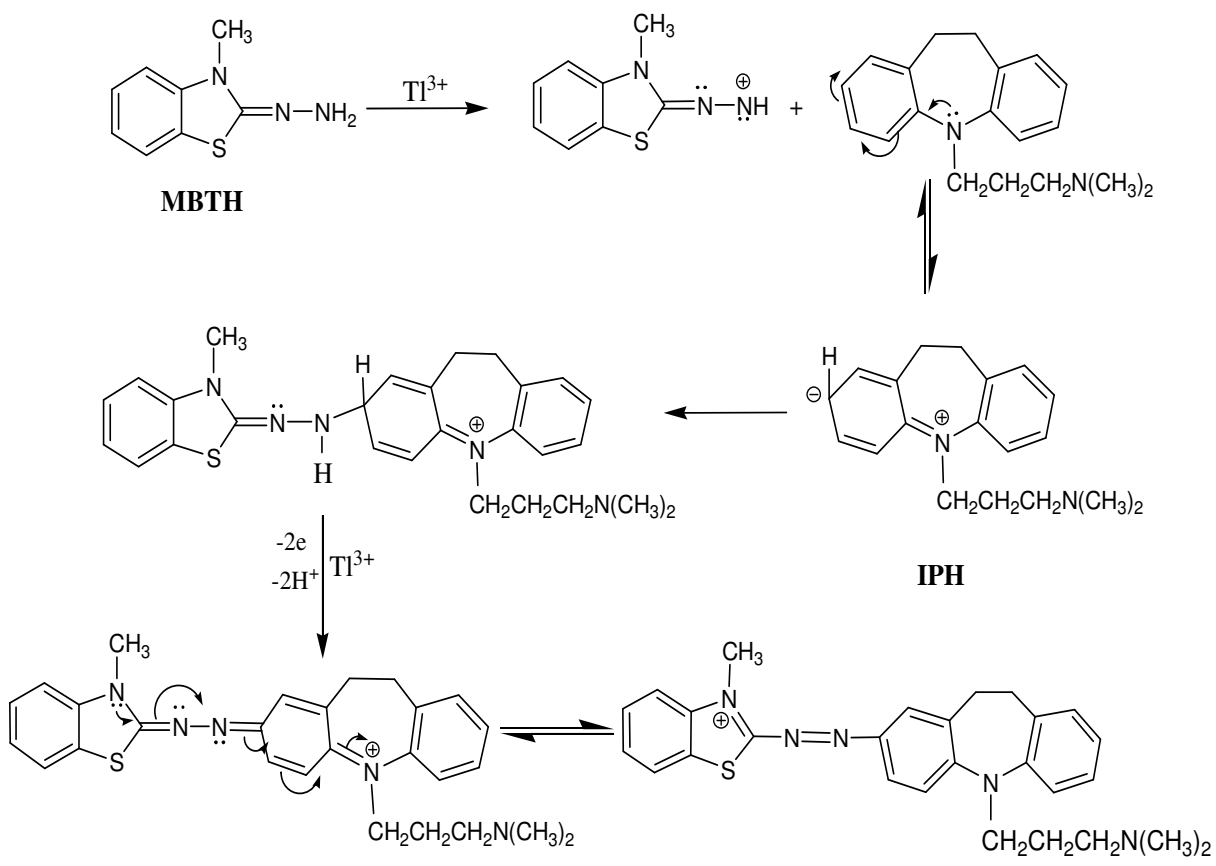

Blue color product

Scheme 1. Reaction pathway for the formation of colored product by MBTH and IPH

Performance of the proposed method and statistical comparison with reported methods

The proposed method was applied for the determination of thallium by spiked environmental and biological samples with known quantity of thallium(III) and carrying out recovery studies. The results obtained by the proposed method were confirmed by measurements of thallium contents using the reported methods ${ }^{32,42}$. The results were analyzed statistically by Student's t-test and the variance ratio F-test at 95\% confidence level. The calculated $\mathrm{t}$ and $\mathrm{F}$-values did not exceed those theoretical values. It is evident from Table 4, that there is no significant difference between the spiked amounts and those detected by proposed method and the reported methods, indicating that the proposed method is as accurate and precise as the reported methods. Comparative study between the proposed method and some reported methods has shown that, the proposed method is simple, rapid, and highly sensitive than these methods in literature as shown in Table 5 .

\section{Application of the method in synthetic mixtures}

Certified samples of thallium were not available so the proposed method was applied to a variety of synthetic samples to evaluate its effectiveness. The composition of the synthetic mixtures was selected to contain the common metal ions that usually accompany thallium in natural samples ${ }^{15}$. The mixtures were analyzed by recommended procedure and the obtained results showed good recoveries for thallium(III) as shown in Table 6. 
Table 4. Determination of Tl(III) in spiked different water and urine samples by a proposed method and reported methods.

\begin{tabular}{|c|c|c|c|c|c|c|c|}
\hline \multirow[b]{2}{*}{ Sample } & \multirow{2}{*}{$\begin{array}{l}\text { Thallium } \\
\text { added } \\
\mu \mathrm{g} \mathrm{mL}\end{array}$} & \multicolumn{2}{|c|}{ Proposed method } & \multicolumn{2}{|c|}{ Reported method $^{32,42}$} & \multirow[b]{2}{*}{$t$-test ${ }^{b}$} & \multirow[b]{2}{*}{ F-test ${ }^{c}$} \\
\hline & & $\begin{array}{l}\text { Thallium } \\
\text { Found }^{\mathrm{a}} \\
\mu \mathrm{g} \mathrm{mL} \mathrm{m}^{-1}\end{array}$ & $\begin{array}{c}\text { Recovery } \\
\%\end{array}$ & $\begin{array}{l}\text { Thallium } \\
\text { Found }^{\mathrm{a}} \\
\mu \mathrm{g} \mathrm{mL}^{-1}\end{array}$ & $\begin{array}{c}\text { Recovery } \\
\%\end{array}$ & & \\
\hline \multirow{3}{*}{$\begin{array}{l}\text { River } \\
\text { water }^{\mathrm{d}, \mathrm{e}}\end{array}$} & 0.5 & $0.496 \pm 2.3$ & 99.2 & $0.502 \pm 1.66$ & 100.4 & 0.95 & 1.86 \\
\hline & 2.0 & $1.998 \pm 0.65$ & 99.9 & $2.006 \pm 0.67$ & 100.3 & 0.96 & 1.06 \\
\hline & 4.0 & $4.002 \pm 0.41$ & 100.05 & $4.006 \pm 0.52$ & 100.15 & 0.34 & 1.59 \\
\hline \multirow{3}{*}{$\begin{array}{l}\text { Lake } \\
\text { water }^{\text {d, f }}\end{array}$} & 0.5 & $0.494 \pm 2.31$ & 98.8 & $0.502 \pm 1.67$ & 100.4 & 1.26 & 1.85 \\
\hline & 2.0 & $1.998 \pm 0.65$ & 99.9 & $2.004 \pm 0.45$ & 100.2 & 0.85 & 2.13 \\
\hline & 4.0 & $3.986 \pm 0.38$ & 99.65 & $3.996 \pm 0.29$ & 99.9 & 1.17 & 1.77 \\
\hline \multirow{3}{*}{$\begin{array}{l}\text { Tap } \\
\text { water }^{\mathrm{d}}\end{array}$} & 0.5 & $0.494 \pm 2.31$ & 98.8 & $0.502 \pm 1.97$ & 100.4 & 1.27 & 1.86 \\
\hline & 2.0 & $1.994 \pm 0.57$ & 99.7 & $1.992 \pm 0.42$ & 99.6 & 0.32 & 1.85 \\
\hline & 4.0 & $3.990 \pm 0.40$ & 99.75 & $3.998 \pm 0.48$ & 99.95 & 0.72 & 1.48 \\
\hline \multirow{3}{*}{$\begin{array}{l}\text { Human } \\
\text { urine }^{d}\end{array}$} & 0.5 & $0.484 \pm 2.36$ & 96.8 & $0.486 \pm 1.84$ & 97.02 & 0.37 & 1.86 \\
\hline & 2.0 & $1.982 \pm 0.42$ & 99.1 & $1.978 \pm 0.43$ & 98.9 & 0.76 & 1 \\
\hline & 4.0 & $3.978 \pm 0.21$ & 99.45 & $3.984 \pm 0.29$ & 99.6 & 0.95 & 1.85 \\
\hline
\end{tabular}

${ }^{a}$ Mean \pm Relative Standard Deviation $(n=5) ;{ }^{b}$ Tabulated $t$-value for eight degrees of freedom at $P$ (0.95) is 2.78; ${ }^{c}$ Tabulated $F$-value for $(4,4)$ degrees of freedom at $P(0.95)$ is 6.39; ${ }^{d}$ Gave no test for thallium; ${ }^{e}$ Kukkaraheli lake-Mysore, India; ${ }^{f}$ Cauvery River-Mysore, India.

Table 5. Comparison of recommended method with reported methods.

\begin{tabular}{|c|c|c|c|c|}
\hline Method & $\begin{array}{l}\text { Beer's Law } \\
\text { range } \\
\mu \mathrm{g} \mathrm{mL}^{-1} \\
\end{array}$ & $\begin{array}{c}\text { Molar } \\
\text { absorptivity, } \\
\mathrm{L} \mathrm{mol}^{-1} \mathrm{~cm}^{-1} \\
\end{array}$ & Remarks & References \\
\hline $\begin{array}{l}9,10 \text {-Phenanthaquinone } \\
\text { monoethylthiosemicarb- } \\
\text { azone }\end{array}$ & $0.2-10$ & $2.2 \times 10^{4}$ & $\begin{array}{l}\text { Separation by flotation and } \\
\text { solid-phase extraction }\end{array}$ & 32 \\
\hline $\begin{array}{l}\text { Methiomeprazine } \\
\text { hydrochloride }\end{array}$ & $0.5-4$ & $3.2 \times 10^{4}$ & $\begin{array}{l}\text { Color Stability less than } \\
\text { 2hours }\end{array}$ & 33 \\
\hline $\begin{array}{l}N, N \text { '-diphenylbenz } \\
\text { amidne }\end{array}$ & $0.1-1.2$ & $1.8 \times 10^{5}$ & Based on the extraction & 34 \\
\hline $\begin{array}{l}\text { 4-(4'-N,N-Dimethyl } \\
\text { aminophenyl) urazol }\end{array}$ & $0.016-6.13$ & - & $\begin{array}{l}\text { Need extraction, control of } \\
\mathrm{pH}, 30^{\circ} \mathrm{C} \text { and high interfere } \\
\text { with } \mathrm{Fe}^{3+}\end{array}$ & 36 \\
\hline Phenosafranine & - & $6.65 \times 10^{4}$ & Several ions interfere & 43 \\
\hline $\begin{array}{l}\text { Trifluperazine } \\
\text { hydrochloride }\end{array}$ & $0.5-6.5$ & $2.14 \times 10^{4}$ & Less sensitive & 44 \\
\hline $\begin{array}{l}\text { Bromopyrogallol red } \\
+ \text { CTAB }\end{array}$ & - & $3.5 \times 10^{4}$ & Several ions interfere & 45 \\
\hline MBTH + IPH & $0.1-5$ & $2.9 \times 10^{4}$ & $\begin{array}{l}\text { Simple, rapid, sensitive, } \\
\text { stable color, less } \\
\text { interference and no } \\
\text { need prior extraction, } \\
\text { control of pH or } \\
\text { temperature. }\end{array}$ & $\begin{array}{l}\text { Proposed } \\
\text { method }\end{array}$ \\
\hline
\end{tabular}


Table 6. Determination of Tl(III) in synthetic mixtures of common metal ions that usually accompany thallium in nature.

\begin{tabular}{cccc}
\hline Mixture & $\begin{array}{c}\text { Thallium(III) } \\
\text { added, } \mu \mathrm{g} \mathrm{ml}\end{array}$ & $\begin{array}{c}\text { Thallium(III) } \\
\text { found }{ }^{\mathrm{b}} \mu \mathrm{g} \mathrm{mL}\end{array}$ & Mean Recovery,\% \\
\hline $\mathrm{Fe}^{3+(\mathrm{a})}, \mathrm{Pb}^{2+}, \mathrm{Zn}^{2+}, \mathrm{Cd}^{2+}, \mathrm{Ni}^{2+}$ & 2 & $1.95 \pm 0.59$ & 97.5 \\
$\mathrm{Fe}^{3+(\mathrm{a})}, \mathrm{Pb}^{2+}, \mathrm{Zn}^{2+}, \mathrm{Cd}^{2+}, \mathrm{Ni}^{2+}$ & 4 & $3.94 \pm 0.38$ & 98.5 \\
$\mathrm{Cu}^{2+}, \mathrm{Zn}^{2+}, \mathrm{Fe}^{3+(\mathrm{a})}, \mathrm{Pb}^{2+}$ & 2 & $1.96 \pm 0.81$ & 98 \\
$\mathrm{Cu}^{2+}, \mathrm{Zn}^{2+}, \mathrm{Fe}^{3+(\mathrm{a})}, \mathrm{Pb}^{2+}$ & 4 & $3.90 \pm 0.34$ & 97.5 \\
\hline${ }^{a} \cdot$ Masking by the addition of 4mL of 0.3M sodium fluoride. & \\
${ }^{b}$. Mean \pm Relative Standard Deviation $(n=5)$ &
\end{tabular}

\section{Conclusion}

The proposed method that involves coupling of MBTH with IPH as new reagents in the determination of thallium(III) has some advantages such as simplicity, selectivity, stability and sensitivity as compared to some reported methods as shown in Table 5. This method has applied for the determination of thallium in urine which is very important to determination of thallium in human body. The color development was maximum and involves less stringent control of experimental conditions including duration for time analysis and $\mathrm{pH}$ control, which make this method easy and more practical as far as the procedure is concerned. In addition, the proposed method neither involves solvent extraction nor employs sophisticated instruments. The method has high tolerance limit for interfering species that are commonly present with thallium which is another added advantage. Thus, it can be concluded that this proposed method can be applied for the determination of thallium in various analytical procedures.

\section{Acknowledgement}

One of the authors (N.G.S. Al-Tayar) is grateful to the Yemen Gas Company and Ministry of Higher Education (Republic of Yemen) for awarding a fellowship. Authors are grateful to the University of Mysore for providing the laboratory facilities and granting permission to carryout the research work.

\section{References}

1. Wallwork-Barber M K, Lyall K and Ferenbaugh R W, J Environ Sci Health, 1985 A20, 689.

2. Sharma J, Sharma R L, Singh H B and Stake M, Toxicol Environ Chem., 1986, 11, 93.

3. Patty F A, Industrial Hygiene and Toxicology, Interscience Publishers, New York, 1962, 2.

4. Younger D S, Pollutants and Industrial Hazards, In: Rowland L P, Editor. Merritt's Textbook of Neurology, $9^{\text {th }}$ Edn. Baltimore M D: Willians and Wilkins, 1995, 992.

5. Townshend A, Ed., Encyclopedia of Analytical Science, Academic Press, London, $1995,9$.

6. Kucera J and Vobecky M J, J Radioanal Nucl Chem., 1997, 217, 131.

7. Mulkey J P and Oehme F W, Vet Human Toxicol., 1993, 35(5), 445.

8. Hassanien M M, Abou-El-Sherbini K H S and Mostafa G A E, Talanta, 2003, 59, 383.

9. Mamoru H, Kazushi T, Mariko O O, Mitsutoshi T and Naomi H, Industrial Health, 1998, 36, 300.

10. Oehme F W, Toxicity of Heavy Metals in the Environment, Marcel Dekker, Inc., New York, 1979, Part-II. 
11. Sitting M, Handbook of Toxic and Hazardous Chemicals and Carcinogens. Noyes Publication, New Jersey, USA, 1985.

12. Lime I, Kaiser G, Sager M and Tolg G, Anal Chim Acta, 1984, 158, 179.

13. Lukaszewski Z, Zembrzuski W and Piela A, Anal Chim Acta, 1996, 318 (2), 159.

14. Ciszewski A, Wasiak W and Ciszewska W, Anal Chim Acta, 1997, 343, 225.

15. Shams E and Yekehtaz M, Anal Sci., 2002, 18(9), 993.

16. Nadia S, Angelo P, Paola C P, Maria I P, Gavino S, Renato S and Andrea T, Anal Chim Acta, 2005, 553, 201.

17. Chamberlain, I, Adams K and Le S, At Spectrosc., 2000, 21(4), 118.

18. Dadfarnia S, Assadollahi T and Haji Shabani A M, J Hazard Mater., 2007, 148, 446.

19. Mohammed A T, Bull Korean Chem Soc., 2003, 24(8), 1177.

20. Hubert A E and Chao T T, Talanta, 1985, 32, 568.

21. Itawi R K and Turel Z R, J Radioanal Nucl Chem., 1987, 115(1), 141.

22. Villar M, Alava F, Lavila I and Bendicho C, J Anal At Spectrom., 2001, 16, 1424.

23. Ivanova E, Yan X P, Mol W V and Adams F, Analyst, 1997, 122, 667.

24. Zendelovska D and Stafilov T, Anal Sci., 2001, 17(3), 425.

25. Zen J M.and Wu J W, Electroanalysis, 1997, 9, 302.

26. Bondelli J E, Taylor H E and Skogerboe R K,. Anal Chim Acta., 1980, 118, 243.

27. Ciszewski A and Lukaszewski Z, Talanta, 1983, 30, 873.

28. Hoeflich L K, Gale R J and Good M L, Anal Chem., 1983, 55, 1591.

29. Agarwal N and Patel K S, Analusis, 1991, 19, 134.

30. Zhang R, Wang H and Wen J, Fenxi Huaxue, Anal Abstr., 1988,16(2), 111.

31. Namboothri K K, Balasubramanian N and Ramakrishna T V, Talanta, 1991, 38, 945.

32. Abou-El-Sherbini K S, Mostafa G A E and Hassanien M M, Anal Sci., 2003, 19, 1269 ,

33. Revanasiddappa H D and Kiran Kumar T N, Turk J Chem., 2005, 29, 265.

34. Deb M K, Agnihotri P K, Thakur M and Mishra R K, Chemical Speciation and Bioavailability, 1998, 10(2), 53.

35. Hosseini M S and Naseri Y, Anal Sci., 2003, 19(11), 1505.

36. Rezae B, Mallkpour S and Khalili H, Can J Anal Sci Spectrosc., 2005, 50(4), 227.

37. Anastas P T and Kirchoff M M, Acc Chem Res., 2002, 35, 686.

38. Gowda H S, Shakunthala R and Subrahamanya U, Indian J Chem., 1981, 20A, 68.

39. Pays M, Bourdon R and Beljean M, Anal Chim Acta., 1969, 47, 101.

40. Eugene S, Thomas W S, Thomas R H, Walter E and James L N, Anal Chem., 1961, 33(6), 722.

41. Hemantha Kumar M S, Nagaraja P, Yathirajan H S and Prakash J S, Fresonius Environmental Bulletin, 2002, 11(7), 396.

42. Ariel M and Bach D, Analyst, 1963, 88, 30.

43. Liu C, Zhou H and Quin L, Fenxi Huaxue, 1986, 14(2), 142.

44. Revanasiddappa H D and Kiran Kumar T N, Anal Sci., 2002, 18(10), 1131.

45. Ladzinsk- Kulinska and Halina, Chem Anal (Warsaw), 1986, 31(5-6), 843. 


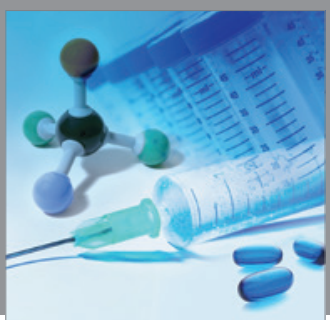

International Journal of

Medicinal Chemistry

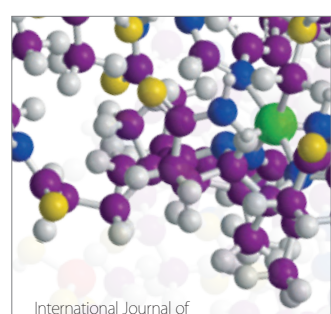

Carbohydrate Chemistry

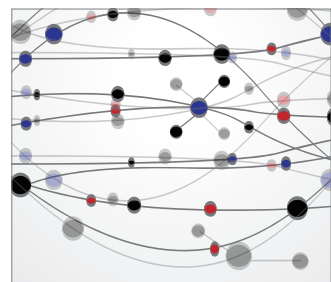

The Scientific World Journal
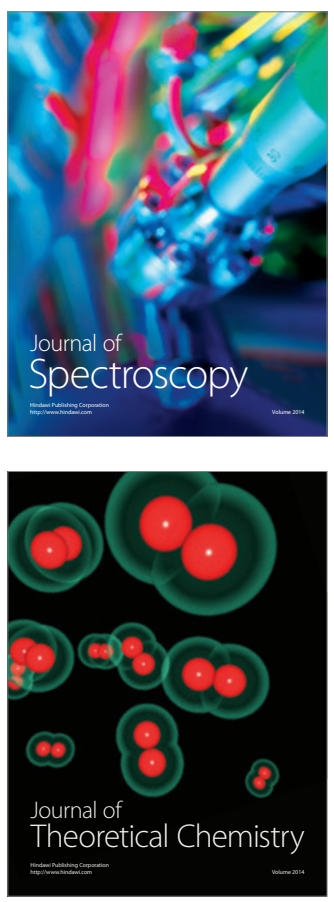
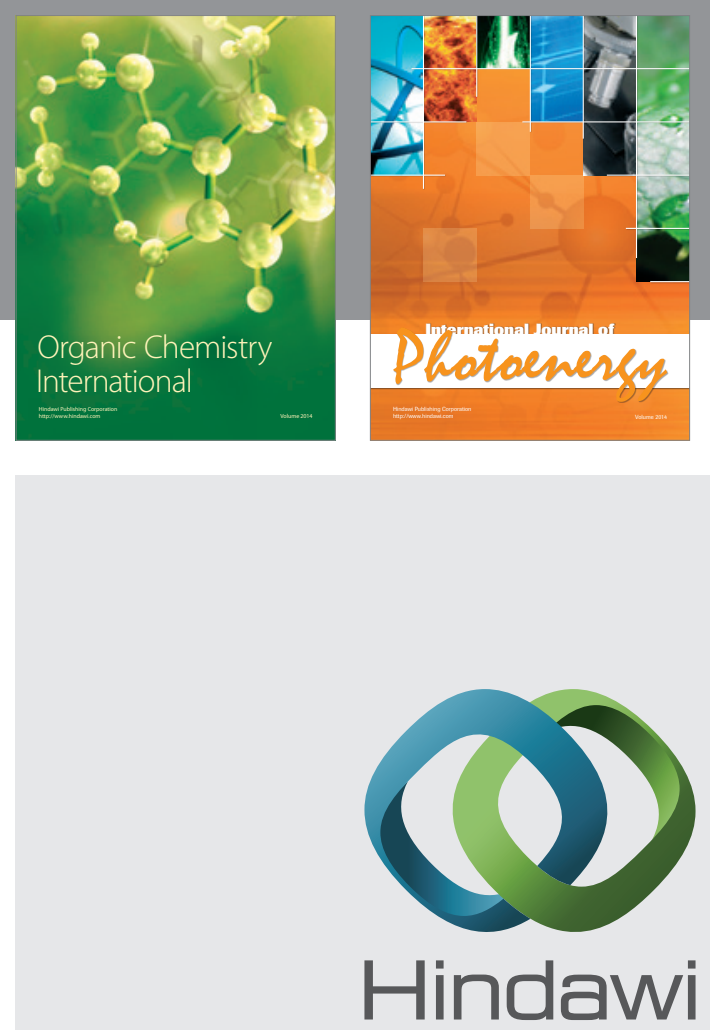

Submit your manuscripts at

http://www.hindawi.com
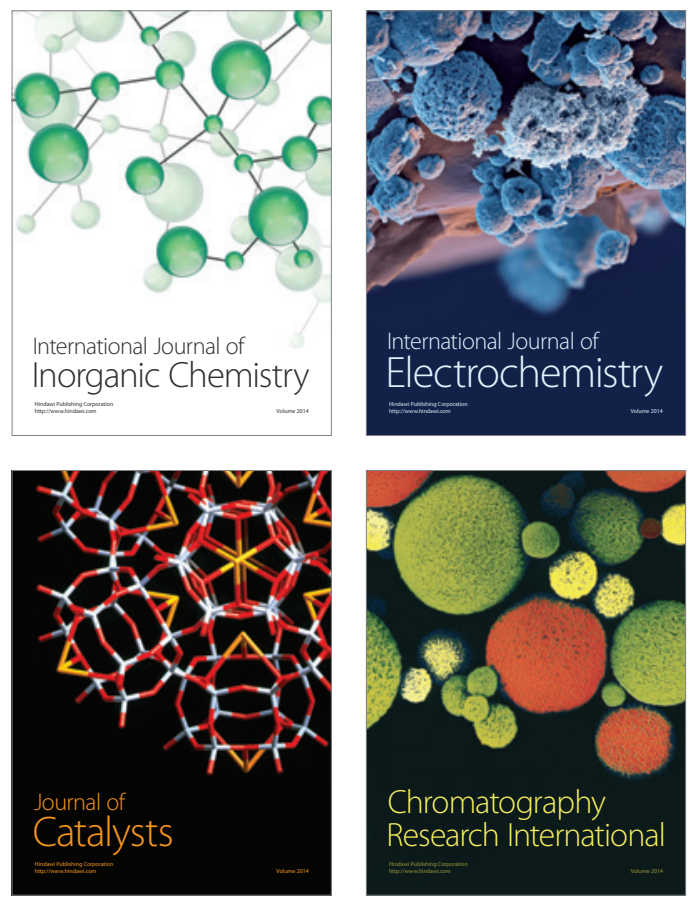
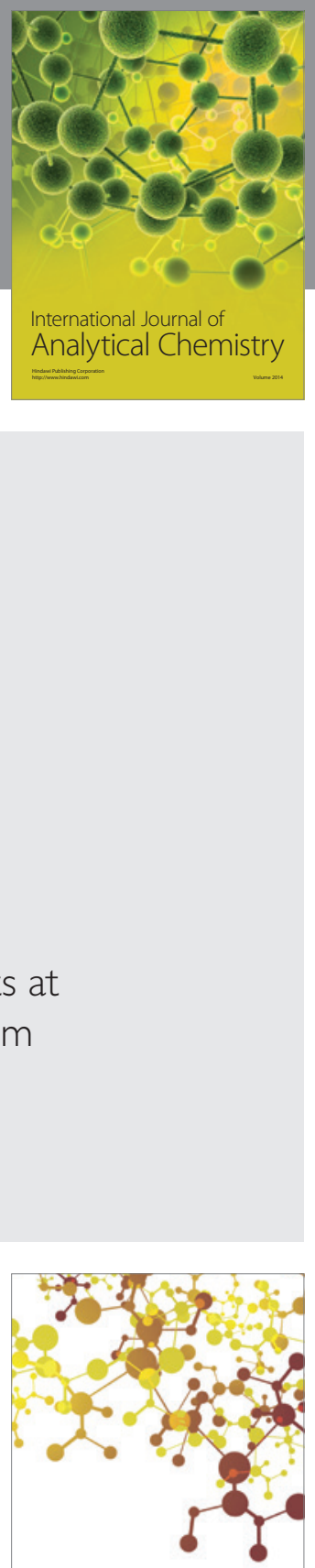

Journal of

Applied Chemistry
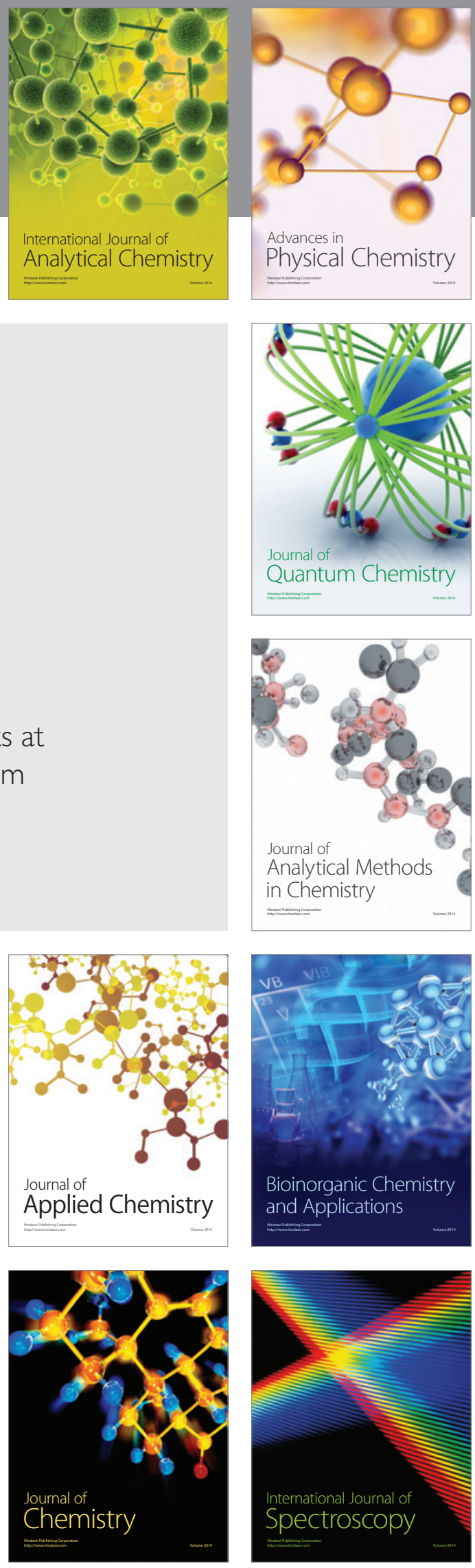